\title{
The Integrated Process Model For Learning Organization
}

Guoquan Chen (Email: chengqu@em.tsinghua.edu.cn), Tsinghua University, Beijing, P.R.China Raymond R. Liu (Email: raymond.liu@umb.edu), University of Massachusetts Boston

\begin{abstract}
This paper proposes an integrated process model of a learning organization, which consists of six processes - "sensing”, “innovating”, "selecting”, “implementing”, “diffusing”, "feedback”, and one base - "knowledge base \& knowledge management". Based on the literature review and the interviews with multinational corporations in China, this model integrates the important organizational learning processes and knowledge management to reflect the reality of learning organizations comprehensively. Based on the integrated model, key elements that affect organizational learning processes are identified. Finally, the contributions, implications, limitation, and future research of the integrated process model are discussed.
\end{abstract}

\section{Introduction}

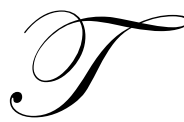

he concept of learning organization has been studied for over two decades (Argyris and Schon 1978, 1996; Daft and Weick 1984; Levitt \& March 1988; Senge 1990; Huber 1991; Argyris 1993; Dodgson 1993; Garvin 1993, 2000; Nason 1994; Morgan 1996; Cross \& Baird 2000; Crossan and Guatto 1996; De Geus 1997; Fulmer, Gibbs, and Keys 1998; Fisher and White 2000; Hodgkinson 2000; Jackson 2000; Beeby and Booth 2000; Vermeulen and Barkema 2001; Schulz 2001; and Wijnhoven 2001). Today, how to turn ordinary organizations into a learning organization is still an important and challenge research area. For instance, research work based on Argyris and Schon's typical 4-process model (Argyris \& Schon, 1978) view organizational learning as consisting of four interrelated linear phases: discovery, invention, production and generalization (Figure 1).

Figure 1. Argyris and Schon's 4-process model for organizational learning (Argyris \& Schon, 1978)

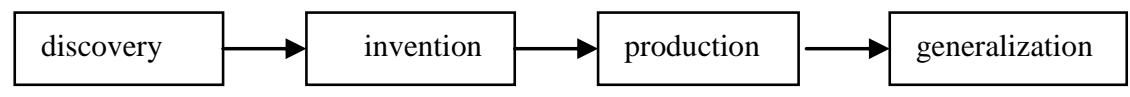

However, a complete learning process should include phrases of "selecting" and "feedback". "Selecting" means making choices from many learning alternatives and find the better or best one to carry out. "Feedback" means "looking backward to look forward" and making adjustments to the value, norm and operation of the organization to meet requirements of the changing environment. In addition, organizational learning should be a process of knowledge accumulation (Cross \& Baird, 2000), sharing (Hansen, Nohria \& Tierney, 1999), and conversion ( Nonaka \& Takeuchi, 1995). Without these knowledge activities, organizational learning cannot evolve from lower to higher levels, and true learning organizations could not exist.

Therefore, we propose an integrated model for a complete learning process of a learning organization to include the "selecting", "feedback", and "knowledge management". The model answers the following questions:

Readers with comments or questions are encouraged to contact the authors via email. 
- What is the intrinsic mechanism for an organization to learn (how does learning actually happen in an organization)?

- What are the key elements of the organizational learning processes?

- $\quad$ Finally, what are the relationships between the organizational learning processes and their key elements?

This paper, first, starts with introducing the new model and its components for a learning organization; second, identifies the key elements that affect the components in the model and develop a set of proposition for the relationships between each component and its affecting elements; and finally, discuss the theoretical and managerial implications of the model and the propositions.

\section{The Integrated Process Model for Learning Organization}

Figure 1. The Integrated Process Model for Learning Organization

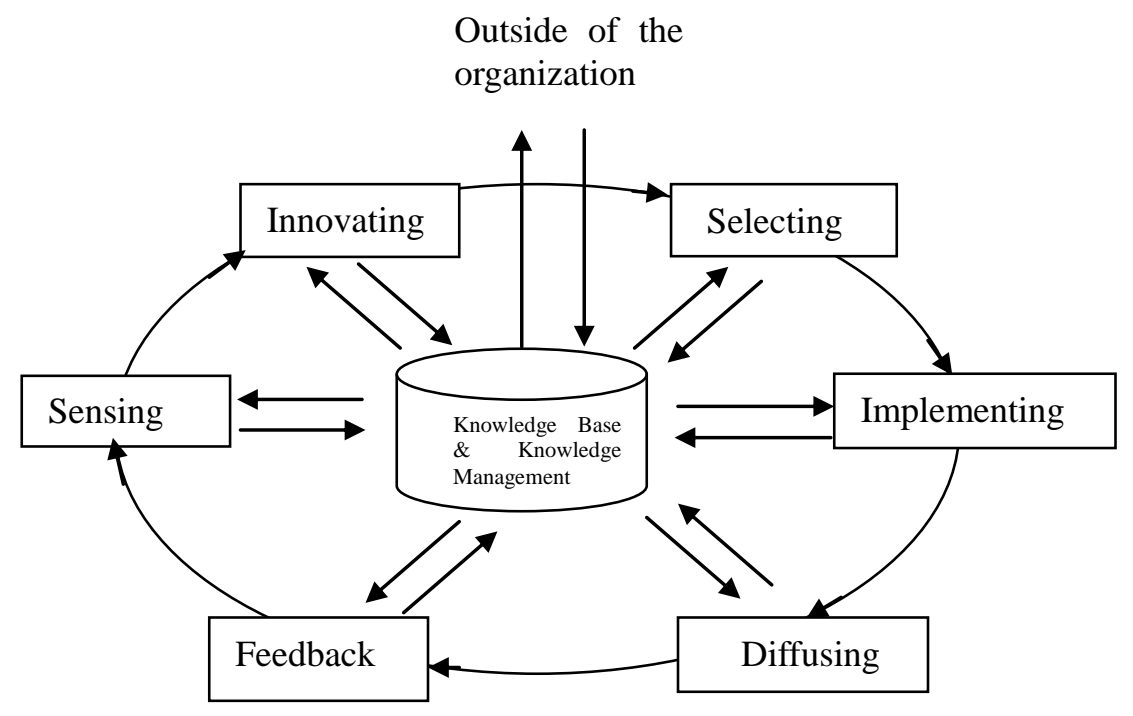

\section{Propositions}

Proposition1: An organizational learning process is composed of the seven sub-processes and they are all interrelated as described in Figure 2.

Proposition 2: The "sensing" process is positively affected by the organization's shared consciousness of crisis, shared vision, and listening and analytical ability.

Proposition 3: The organization's innovative consciousness, innovative thinking, total employee innovation, teamwork and team learning, freedom and autonomy, and incentive system positively affect the "innovating" process.

Proposition 4: the organization's redundancy, requisite variety, open system, HRM policy, and management decision system positively affect the "selecting" process.

Proposition 5: the organization's commitment, communications, "PRC" system, concrete and operable procedure, incremental implementation process, use of external experts, focused change initiatives, systematic planning, and non-equilibrium state positively affect the "implementing" process. 
Proposition 6: the organization's consciousness of knowledge sharing, incentive system, and knowledge diffusing mechanisms positively affect the "diffusing" process.

Proposition 7: the organization's consciousness of self-reviewing and self-criticizing, and data collecting, analyzing, and transferring system positively affect the "feedback" process.

Proposition 8: the organization's knowledge accumulation, knowledge sharing, knowledge protecting, and knowledge conversion positively affect the "knowledge management" process.

\section{Discussion}

In this article, we propose an integrated model of organizational learning and identify the key elements that affect the processes in the model. The integrated model of learning organization provides a comprehensive, dynamic and spiral view on organizational learning and learning organization. Organizational learning goes through the following steps: (1) an organization "senses" the changes, potential problems or opportunities in the external environment or within the company's own system, then (2) "innovates" new solutions, such as a new product or service, business processes or management practices, to deal with the above mentioned external and internal changes, problems or opportunities, (3) then "selects" the most suitable or best one from among all alternatives, (4) then "implements" the best or better choice in the organization exactly once it is selected, (5) then "diffuses" the best or better choice originating from one point (such as an individual, a team or a department somewhere in the organization) to relevant units within or even outside the organization to reduce repeated efforts and to facilitate full utilization of the organization's resources, (6) then evaluates the effectiveness of the best or better choice and makes continuous adjustments to meet the changing demand of the environment ("feedback"), (7) and finally during the "knowledge management" stage, knowledge generated during each sub-process will be accumulated, shared, conversed and protected within the organization.

\section{References}

1. Argyris, C., \& Schon, D.A. 1978. Organizational learning: A theory of action perspective. Reading, MA: Addison-Wesley.

2. Argyris, C., \& Schon, D.A. 1996. Organizational learning II: Theory, method and practice. Reading, MA: Addison-Wesley.

3. Beeby, M. \& Booth, B. 2000. "Networks and inter-organizational learning: a critical review". The Learning Organization, 7(2): 75-88.

4. Cross, R., \& Baird, L. 2000. "Technology is not enough: Improving performance by building organizational memory". Sloan Management Review. Spring: 69-78.

5. Crossan, M. \& Guatto, T. 1996. "Organizational learning research profile". Journal of Organizational Change Management. 9(1): 107.

6. Daft, R.L., \& Weick, K. 1984. "Toward a model of organizations as interpretive systems". Academy of Management Review. 9 (2) : 284-295.

7. De Geus, A. 1997. The living company. Boston, MA: Harvard Business School Press.

8. Dodgson, M. 1993. "Organizational learning: A review of some literatures". Organization Studies. 14/3: 375-394.

9. $\quad$ Fisher, S.R., \& White, M.A. 2000. "Downsizing in a learning organization: Are there hidden costs?" Academy of Management Review. 25(1): 244-251.

10. Hansen, M.T., Nohria, N., \& Tierney, T. 1999. “What's your strategy for managing knowledge?" Harvard Business Review. March-April: 106-116.

11. Hodgkinson, M. 2000. "Managerial perceptions of barriers to becoming a 'learning organization"'. The learning Organization, 7(3): 156-166.

12. Huber, G.P. 1991 "Organizational learning: The contributing processes and the literatures". Organization science. 2: 88-115.

13. Levitt, B. \& March, J.G. 1988. “Organizational Learning”. Annual Review of Sociology, 14: 319-340.

14. Morgan, G. 1996. Images of Organization. Newbury Park: Sage. 
15. Nonaka, I., \& Takeuchi, H. 1995. The knowledge creating company: How Japanese companies create the dynamics of innovation. (New York) Oxford: Oxford University Press.

16. Schulz, M. 2001. "The uncertain relevance of newness: Organizational learning and knowledge flows". Academy of Management Journal, 44(4): 661-681.

17. Senge, P. M.1990. The fifth discipline: The art and practice of the learning organization. New York: Doubleday Currency.

18. Vermeulen, F. \& Barkema, H. 2001. "Learning through acquisitions". Academy of Management Journal, 44(3): 457-476.

19. Wijnhoven, F. 2001. "Acquiring organizational learning norms: A contingency approach for understanding deutero learning”. Management Learning, 32(2): 181-200.

Notes 